\title{
Comparison of Bankruptcy Prediction Models: Evidence from India
}

\author{
Varadraj Bapat $^{1} \&$ Abhay Nagale ${ }^{2}$ \\ ${ }^{1}$ Shailesh J. Mehta School of Management, Indian Institute of Technology Bombay, India \\ ${ }^{2}$ Shailesh J. Mehta School of Management, Indian Institute of Technology Bombay, India \\ Correspondence: Abhay Nagale, 7, Shree Sadan, Sane Guruji Nagar, Mulund (East), Mumbai 400081, Maharashtra, \\ India Tel: 91-98-2047-7580 E-mail: abhaynagale@yahoo.co.in
}

Received: September 23, 2014

Accepted: October 12, 2014

Online Published: October 15, 2014

doi:10.5430/afr.v3n4p91

URL: http://dx.doi.org/10.5430/afr.v3n4p91

\begin{abstract}
The purpose of this paper is to develop and compare the performance of bankruptcy prediction models using multiple discriminant analysis, logistic regression and neural network for listed companies in India. Accordingly bankruptcy prediction models are developed, over the three years prior to bankruptcy using financial ratios. The sample consists of 72 bankrupt and 72 non-bankrupt companies over the period 1991-2013. The results indicate that compared to multiple discriminant analysis and logistic regression, neural network has the highest classification accuracy for all the three years prior to bankruptcy. This study will be useful to financial institutions, investors, creditors and auditors to identify companies that are likely to experience bankruptcy.
\end{abstract}

Keywords: Bankruptcy prediction, Multiple discriminant analysis, Logistic regression, Neural network, India

\section{Introduction}

Bankruptcy prediction is among the most well researched topics in the finance and strategic management literature (Polemis \& Gounopoulos, 2012). The early researchers (Ramser \& Foster, 1931; Fitzpatrick, 1932; Winakor \& Smith, 1935; Merwin, 1942) focused on the comparison of the values of financial ratios in bankrupt and non-bankrupt companies and concluded that the ratios of the bankrupt companies were poorer (Ugurlu \& Aksoy, 2006). Altman (1968) used multiple discriminant analysis for prediction of corporate bankruptcy. In the 1970s, multiple discriminant analysis was the primary method for prediction of corporate bankruptcy. During the 1980s, use of logistic regression analysis method was emphasized, (Virag \& Kristof, 2005). Ohlson (1980) applied logistic regression analysis for the first time for prediction of bankruptcy. In recent years, a number of researchers have begun to apply the neural network approach to the prediction of bankruptcy as they have produced promising results in prediction of bankruptcy (Ugurlu \& Aksoy, 2006). Neural networks were first used for bankruptcy prediction by Odom and Sharda (1990).

The objective of this study is to construct bankruptcy prediction models with data of Indian listed companies using multiple discriminant analysis, logistic regression and neural network and compare the performance of the three models. It is hoped that findings of this study will serve to assist bankers, lenders, investors, managers, auditors and other finance related personnel, in their financial and managerial decision making.

Section 2 of this paper provides the evidence presented in literature. The methodology is presented in section 3 . Section 4 presents the findings of the study and conclusions are presented in section 5 .

\section{Literature Review}

Various researchers' have compared the performance of different methods of bankruptcy prediction. However not much research has been done using the data from Indian companies. Odom and Sharda (1990) compared the performance of neural network and discriminant analysis using data of 74 companies based on Altman's (1968) five financial ratios. They found that the neural network model gave better results than discriminant analysis. Of the bankrupt companies $18.5 \%$ were inaccurately classified as non-bankrupt with the neural network method, as against $40.7 \%$ with discriminant analysis.

Salchenberger, Cinar and Lash (1992) compared neural networks and logistic regression. On comparison of classification accuracy it was observed that neural networks performed considerably better than logistic regression. 
Coats and Fant (1993) compared the performance of multiple discriminant analysis and neural networks. Classification accuracy of neural network was $95.0 \%$ and that of multiple discriminant analysis was $87.9 \%$.

Kerling and Poddig (1994) used the database of French companies to compare neural networks and discriminant analysis. Neural network gave $87.7 \%$ accuracy while discriminant analysis gave $85.7 \%$ accuracy.

Zhang, Hu, Patuwo and Indro (1999) compared between neural network and logistic regression, on a sample of manufacturing firms. They used Altman's five financial ratios plus the ratio current assets/current liabilities as inputs to the neural network. The neural network significantly outperformed logistic regression with accuracy of $88.2 \%$ versus $78.6 \%$.

Charitou, Neophytou and Charalambous (2004) developed bankruptcy prediction models for UK industrial firms using neural networks and logistic regression methods. The results indicate that the neural network model achieved the highest overall classification rates for all three years prior to insolvency, with an average classification rate of $78 \%$ while the logistic regression model achieved an average classification of $76 \%$.

Virag and Kristof (2005) did a comparative study of bankruptcy prediction models on the database of Hungarian companies. They concluded that bankruptcy models built using neural networks have higher classification accuracy than models based on multiple discriminant analysis and logistic regression.

However in case of some studies the results were unsettled. Altman, Marco and Varetto (1994) applied neural network and multiple discriminant analysis to large database of 1000 Italian firms for one year prior to bankruptcy. The comparison yielded no decisive winner

Boritz and Kennedy (1995) compared between a number of techniques, including different neural network training procedures, logistic regression and multiple discriminant analysis, using the indicators chosen by Altman, and those chosen by Ohlson. The results of the comparison are also inconclusive.

Based on international experience a comparative study is necessary to see whether international trends prevail in Indian bankruptcy prediction models as well.

\section{Methodology}

\subsection{Dataset}

We have seen earlier that a large number of researchers have worked on the prediction of bankruptcy. Majority of these studies have defined bankruptcy legalistically. In India there is no single comprehensive and integrated policy on corporate bankruptcy. The rules related to bankruptcy are covered in the Companies Act, 1956 and the Sick Industrial Companies Act, 1985. In this study we consider bankrupt company as a company which is delisted from the stock market and which meets the definition of sick company as per Sick Industrial Companies Act, 1985. As per this act a sick company is one whose accumulated losses exceed its net worth, i.e. whose net worth has become negative. So the bankrupt companies in this study are those companies which were delisted from Bombay Stock Exchange or National Stock Exchange and whose latest net worth and the net worth prior to the year of delisting is negative. For the bankrupt companies the year of bankruptcy will be the year in which its net worth became negative. For e.g. if a company is delisted in the year 2002 and its net worth has become negative in the year 1995 then the year 1995 has been considered as the year of bankruptcy. Financial institutions, delisted companies merged with other companies and companies for whom at least three years full financial statements prior to the year of bankruptcy were not available are excluded from this study.

Economic liberalisation in India started in the year 1991 and after that major structural changes took place in the Indian economy. So the period considered in this study spans from 1991 to 2013. Application of the above mentioned bankruptcy definition in this period resulted in a sample of 72 bankrupt companies. Similar to Altman's (1968) procedure, we chose a twin company that did not bankrupt from the same industry and approximately matched for asset size prior to the year of bankruptcy. This procedure has also been applied in majority of previous bankruptcy prediction studies. The main reason for matched pairing the companies for developing bankruptcy models is to isolate key factors which distinguish otherwise similar firms (Morris, 1997). Thus the total sample consisted of 144 companies.

The bankrupt and non-bankrupt companies are randomly split to create distinct analysis and holdout samples. The analysis sample contains 50 bankrupt and 50 non-bankrupt companies and the holdout sample contains 22 bankrupt and 22 non-bankrupt companies. 


\subsection{Selection of Predictor Variables}

Like previous researchers who have used financial accounting ratios in their empirical studies of bankruptcy prediction, this study also employs financial ratios for development of bankruptcy prediction models. Previous studies have revealed a large number of significant predictors of bankruptcy which can be used for developing bankruptcy prediction models for Indian companies. So in this study 35 financial ratios, proved to be successful in prior studies are employed.

Table 1. List of Financial Ratios

\begin{tabular}{|c|c|c|}
\hline Category & Variable Name & Variable Definition \\
\hline \multirow[t]{5}{*}{ Leverage } & RE/TA & Retained Earnings/Total Assets \\
\hline & $\mathrm{SF} / \mathrm{TA}$ & Shareholders' Fund/Total Assets \\
\hline & $\mathrm{SF} / \mathrm{TD}$ & Shareholders' Fund/Total Debt \\
\hline & $\mathrm{SF} / \mathrm{TL}$ & Shareholders' Fund/Total Liabilities \\
\hline & TL/TA & Total Liabilities/Total Assets \\
\hline \multirow[t]{6}{*}{ Operating Cash Flow } & $\mathrm{CF} / \mathrm{TA}$ & Cash Flow from Operations/Total Assets \\
\hline & $\mathrm{CF} / \mathrm{CL}$ & Cash Flow from Operations/Current Liability and Provisions \\
\hline & $\mathrm{CF} / \mathrm{SF}$ & Cash Flow from Operations/Shareholders' Fund \\
\hline & $\mathrm{CF} / \mathrm{SALE}$ & Cash Flow from Operations/Sales \\
\hline & $\mathrm{CF} / \mathrm{TL}$ & Cash Flow from Operations/Total Liabilities \\
\hline & $\mathrm{AR} / \mathrm{CF}$ & Accounts Receivables/Cash Flow from Operations \\
\hline \multirow[t]{7}{*}{ Liquidity } & $\mathrm{CA} / \mathrm{TA}$ & Current Assets/Total Assets \\
\hline & $\mathrm{CA} / \mathrm{CL}$ & Current Assets/Current Liability and Provisions \\
\hline & $\mathrm{CL} / \mathrm{TA}$ & Current Liability and Provisions/Total Assets \\
\hline & $\mathrm{CL} / \mathrm{SF}$ & Current Liability and Provisions/Shareholders' Fund \\
\hline & $\mathrm{CL} / \mathrm{TL}$ & Current Liability and Provisions/Total Liabilities \\
\hline & $\mathrm{QA} / \mathrm{TA}$ & Quick Assets/Total Assets \\
\hline & $\mathrm{QA} / \mathrm{CL}$ & Quick Assets/Current Liability and Provisions \\
\hline \multirow[t]{8}{*}{ Profitability } & $\mathrm{WC} / \mathrm{TA}$ & Working Capital/Total Assets \\
\hline & $\mathrm{EBIT} / \mathrm{TA}$ & Earnings before Interest and Tax/Total Assets \\
\hline & EBIT/CL & Earnings before Interest and Tax/Current Liability and Provisions \\
\hline & EBIT/FA & Earnings before Interest and Tax /Fixed Assets \\
\hline & $\mathrm{EBIT} / \mathrm{SF}$ & Earnings before Interest and Tax /Shareholders' Fund \\
\hline & $\mathrm{EBIT} / \mathrm{TL}$ & Earnings before Interest and Tax /Total Liabilities \\
\hline & NI/SALE & Net Income/Sales \\
\hline & $\mathrm{NI} / \mathrm{SF}$ & Net Income/Shareholders' Fund \\
\hline \multirow[t]{7}{*}{ Activity } & CA/SALE & Current Assets/Sales \\
\hline & INV/SALE & Inventory/Sales \\
\hline & SF/SALE & Shareholders' Fund/Sales \\
\hline & QA/SALE & Quick Assets/Sales \\
\hline & SALE/CA & Sales/Current Assets \\
\hline & SALE/TA & Sales/Total Assets \\
\hline & SALE/FA & Sales/Fixed Assets \\
\hline \multirow[t]{2}{*}{ Market } & $\mathrm{MV} / \mathrm{TD}$ & Market Value of Equity/Total Debt \\
\hline & $\mathrm{MV} / \mathrm{SF}$ & Market Value of Equity/Shareholders' Fund \\
\hline
\end{tabular}

The list of selected ratios is presented in Table 1. This study uses financial data from the Prowess database of Center for Monitoring Indian Economy. The data sample consisted of the company's financial ratios one year (Year-1), two year (Year -2) and three year (Year -3) prior to year of bankruptcy. In case of non-bankrupt company data for the same year has been considered as is considered for its matched bankrupt company. 


\subsection{Multiple Discriminant Analysis}

Discriminant analysis is a statistical technique used to classify and/or make predictions in problems where the dependent variable appears in qualitative form, e.g., male or female, bankrupt or non-bankrupt. It represents the best way of classifying observations into one of several defined groupings - known as a priori groups - dependent upon the observation's individual characteristics. When classifying companies, the financial ratios are to be put into the discriminant function making up the linear combination. By comparing the discriminant values that separate bankrupt and non-bankrupt companies, one can determine which group a certain company belongs to. The general form of the discriminant function is the following:

$\mathrm{Z}=\mathrm{b}_{0}+\mathrm{b}_{1} \mathrm{x}_{1}+\mathrm{b}_{2} \mathrm{x}_{2}+\ldots .+\mathrm{b}_{\mathrm{n}} \mathrm{x}_{\mathrm{n}}$

where

$\mathrm{Z}=$ discriminant score

$\mathrm{b}_{0}=$ estimated constant

$b_{\mathrm{n}}=$ estimated coefficients

$\mathrm{x}_{\mathrm{n}}=$ independent variables.

\subsection{Logistic Regression}

Logistic regression is a specialised form of regression that is formulated to predict and explain a binary (two-group) categorical variable rather than a metric-dependent measurement (Ong, Yap \& Roy, 2011). Logistic regression utilizes the coefficients of the independent variables to predict the probability of occurrence of a dichotomous dependent variable (Dielman, 1996). In the context of bankruptcy prediction, the technique weighs the financial ratios and creates a score for each company in order to be classified as bankrupt or non-bankrupt. The function in logistic regression is called the logistic function and can be written as follows:

$\mathrm{p}_{\mathrm{i}}=1 /\left(1+\mathrm{e}_{\mathrm{i}}^{-\mathrm{z}}\right)$

where

$\mathrm{p}_{\mathrm{i}}=$ the probability the ith case experiences the event of interest

$\mathrm{z}_{\mathrm{i}}=$ the value of the unobserved continuous variable for the ith case.

\subsection{Neural Network}

Neural networks are inspired by neurobiological systems. Robert Hecht-Nielsen, inventor of one of the earliest neurocomputers, defines a neural network as a computing system made up of a number of simple, highly interconnected processing elements which process information by their dynamic state responses to external inputs (Caudill, 1989). Neural networks are used for many predictive data mining applications because of their power, flexibility, and ease of use. Predictive neural networks are particularly useful in applications where the underlying process is complex, such as: forecasting consumer demand to streamline production or scoring an applicant to determine the risk of extending credit to the applicant. When the distinction between survival and failure is a fine one, neural network technology can be a promising tool for solving the classification problem, i.e. the problem of classifying an entity into one of a finite collection of groups based on the attributes of that entity (Cybinski, 2001).

Neural network is a function of predictors (also called inputs or independent variables) that minimize the prediction error of target variables (also called outputs). An artificial neural network is layered; each of these layers has several neurons that are connected to other neurons belonging to the preceding and following layer (Bredart, 2014). The neural network architecture consists of the following:

a) The input layer containing the predictors.

b) The hidden layer containing unobservable nodes, or units. The value of each hidden unit is some function of the predictors.

c) The output layer containing the responses. Since the history of bankruptcy is a categorical variable with two categories, it is recoded as two indicator variables.

\section{Empirical Results}

\subsection{Descriptive Statistics}

To identify any difference between bankrupt and non-bankrupt companies descriptive statistics are calculated based on financial ratios one year prior to bankruptcy. Table 2 presents a summary of the statistics 
Table 2. Summary Statistics

\begin{tabular}{|c|c|c|c|c|c|c|c|c|}
\hline & \multicolumn{2}{|c|}{ Non-Bankrupt } & \multicolumn{2}{|c|}{ Bankrupt } & \multicolumn{2}{|r|}{ Total } & \multirow[b]{2}{*}{$\mathrm{F}$} & \multirow[b]{2}{*}{ Sig. } \\
\hline & Mean & $\begin{array}{l}\text { Std. } \\
\text { Deviation }\end{array}$ & Mean & $\begin{array}{l}\text { Std. } \\
\text { Deviation }\end{array}$ & Mean & $\begin{array}{l}\text { Std. } \\
\text { Deviation }\end{array}$ & & \\
\hline RE/TA & 0.150 & 0.199 & -0.100 & 0.341 & 0.025 & 0.305 & 28.885 & $0.000^{* *}$ \\
\hline $\mathrm{SF} / \mathrm{TA}$ & 0.367 & 0.152 & 0.212 & 0.144 & 0.289 & 0.167 & 39.549 & $0.000 * *$ \\
\hline $\mathrm{SF} / \mathrm{TD}$ & 1.998 & 3.553 & 0.485 & 0.445 & 1.241 & 2.635 & 12.847 & $0.000 * *$ \\
\hline $\mathrm{SF} / \mathrm{TL}$ & 0.876 & 1.090 & 0.343 & 0.310 & 0.610 & 0.842 & 15.925 & $0.000^{* *}$ \\
\hline TL/TA & 0.575 & 0.165 & 0.730 & 0.146 & 0.653 & 0.174 & 35.468 & $0.000 * *$ \\
\hline $\mathrm{CF} / \mathrm{TA}$ & 0.091 & 0.080 & 0.042 & 0.088 & 0.066 & 0.087 & 12.405 & $0.001 * *$ \\
\hline $\mathrm{CF} / \mathrm{CL}$ & 0.527 & 0.547 & 0.167 & 0.894 & 0.347 & 0.760 & 8.478 & $0.004^{* *}$ \\
\hline $\mathrm{CF} / \mathrm{SF}$ & 0.283 & 0.288 & 0.343 & 1.741 & 0.313 & 1.244 & 0.083 & 0.773 \\
\hline CF/SALE & 0.105 & 0.142 & -0.002 & 0.312 & 0.052 & 0.248 & 6.936 & $0.009^{* *}$ \\
\hline $\mathrm{CF} / \mathrm{TL}$ & 0.156 & 0.201 & 0.060 & 0.129 & 0.108 & 0.175 & 11.712 & $0.001^{* *}$ \\
\hline $\mathrm{AR} / \mathrm{CF}$ & 3.433 & 22.810 & -1.269 & 16.730 & 1.082 & 20.072 & 1.990 & 0.161 \\
\hline $\mathrm{CA} / \mathrm{TA}$ & 0.440 & 0.163 & 0.348 & 0.210 & 0.394 & 0.193 & 8.492 & $0.004^{* *}$ \\
\hline $\mathrm{CA} / \mathrm{CL}$ & 2.441 & 1.365 & 2.461 & 3.199 & 2.451 & 2.451 & 0.002 & 0.961 \\
\hline $\mathrm{CL} / \mathrm{TA}$ & 0.233 & 0.153 & 0.196 & 0.128 & 0.215 & 0.142 & 2.409 & 0.123 \\
\hline $\mathrm{CL} / \mathrm{SF}$ & 0.846 & 1.077 & 2.170 & 3.481 & 1.508 & 2.652 & 9.512 & $0.002 * *$ \\
\hline $\mathrm{CL} / \mathrm{TL}$ & 0.443 & 0.350 & 0.270 & 0.166 & 0.356 & 0.286 & 14.320 & $0.000^{* *}$ \\
\hline QA/TA & 0.234 & 0.122 & 0.204 & 0.162 & 0.219 & 0.143 & 1.586 & 0.210 \\
\hline $\mathrm{QA} / \mathrm{CL}$ & 1.254 & 0.753 & 1.355 & 1.609 & 1.304 & 1.253 & 0.234 & 0.629 \\
\hline $\mathrm{WC} / \mathrm{TA}$ & 0.207 & 0.154 & 0.152 & 0.184 & 0.180 & 0.171 & 3.730 & 0.055 \\
\hline EBIT/TA & 0.106 & 0.060 & -0.012 & 0.176 & 0.047 & 0.144 & 28.946 & $0.000^{* *}$ \\
\hline EBIT/CL & 0.611 & 0.539 & -0.032 & 1.195 & 0.290 & 0.978 & 17.299 & $0.000 * *$ \\
\hline EBIT/FA & 0.356 & 0.327 & -0.006 & 0.429 & 0.175 & 0.421 & 32.291 & $0.000 * *$ \\
\hline EBIT/SF & 0.334 & 0.242 & -0.270 & 2.000 & 0.032 & 1.451 & 6.470 & $0.012^{*}$ \\
\hline EBIT/TL & 0.199 & 0.129 & -0.007 & 0.219 & 0.096 & 0.207 & 47.231 & $0.000^{* *}$ \\
\hline NI/SALE & 0.029 & 0.138 & -0.567 & 2.494 & -0.269 & 1.785 & 4.101 & $0.045^{*}$ \\
\hline $\mathrm{NI} / \mathrm{SF}$ & 0.099 & 0.186 & -1.415 & 2.899 & -0.658 & 2.184 & 19.557 & $0.000^{* *}$ \\
\hline CA/SALE & 0.659 & 1.470 & 0.667 & 0.431 & 0.663 & 1.079 & 0.002 & 0.967 \\
\hline INV/SALE & 0.399 & 1.426 & 0.281 & 0.254 & 0.340 & 1.022 & 0.478 & 0.490 \\
\hline SF/SALE & 0.515 & 0.600 & 0.629 & 0.914 & 0.572 & 0.773 & 0.786 & 0.377 \\
\hline QA/SALE & 0.260 & 0.194 & 0.385 & 0.331 & 0.323 & 0.278 & 7.712 & $0.006^{* *}$ \\
\hline SALE/CA & 3.047 & 2.319 & 1.907 & 1.266 & 2.477 & 1.947 & 13.399 & $0.000 * *$ \\
\hline SALE/TA & 1.256 & 0.880 & 0.607 & 0.479 & 0.931 & 0.777 & 30.187 & $0.000 * *$ \\
\hline SALE/FA & 4.177 & 3.886 & 2.048 & 2.388 & 3.113 & 3.387 & 15.687 & $0.000 * *$ \\
\hline MV/TD & 2.042 & 3.122 & 0.345 & 0.400 & 1.194 & 2.375 & 20.943 & $0.000 * *$ \\
\hline $\mathrm{MV} / \mathrm{SF}$ & 1.311 & 1.979 & 1.396 & 1.863 & 1.354 & 1.916 & 0.071 & 0.791 \\
\hline
\end{tabular}

** $1 \%$ significant level

* $5 \%$ significant level

4.2 Discriminant Analysis

In this study a stepwise selection technique was employed to develop the discriminant analysis. The stepwise method, involves introducing the ratios into the discriminant function one at a time on the basis of their discriminating power. The bankruptcy prediction models are presented below:

Year-1: $\mathrm{Z}=4.999 \mathrm{xSF} / \mathrm{TA}+0.963 \mathrm{xEBIT} / \mathrm{FA}+0.731 \mathrm{xSALE} / \mathrm{TA}-2.271$

Year $-2: Z=5.057 x E B I T / T L+1.053 x S A L E / T A-1.743$ 
Year $-3: \mathrm{Z}=-0.246 \mathrm{xCL} / \mathrm{SF}+3.862 \mathrm{xEBIT} / \mathrm{TL}+0.882 \mathrm{x} \mathrm{SALE} / \mathrm{TA}-1.196$

In the above functions the cut-off point is 0 . The cut-off point indicates that firms with $Z$ score greater than 0 are predicted as non-bankrupt and firms with $\mathrm{Z}$ score less than 0 are predicted as bankrupt. The Model performance is evaluated using the overall accuracy rate. Overall accuracy is based on the total number of correct classifications.

Table 3. Classification Results- Multiple Discriminant Analysis

\begin{tabular}{|c|c|c|c|c|c|}
\hline & \multicolumn{4}{|c|}{ Predicted } \\
\hline & & & Non-Bankrupt & Bankrupt & Percent Correct \\
\hline \multirow[t]{3}{*}{ Year -1} & Observed & Non-Bankrupt & 15 & 7 & 68.18 \\
\hline & & Bankrupt & 6 & 16 & 72.73 \\
\hline & Overall Percent Correct & & & & 70.45 \\
\hline \multirow[t]{3}{*}{ Year -2} & Observed & Non-Bankrupt & 13 & 9 & 59.09 \\
\hline & & Bankrupt & 8 & 14 & 63.64 \\
\hline & Overall Percent Correct & & & & 61.36 \\
\hline \multirow[t]{3}{*}{ Year -3} & Observed & Non-Bankrupt & 15 & 7 & 68.18 \\
\hline & & Bankrupt & 10 & 12 & 54.55 \\
\hline & Overall Percent Correct & & & & 61.36 \\
\hline
\end{tabular}

The results obtained by using multiple discriminant analysis on the holdout sample are presented in Table 3 . It is observed that the accuracy rates fall from 70.45 per cent one year prior to bankruptcy to 61.36 per cent for years two and three prior to bankruptcy.

\subsection{Logistic Regression}

Stepwise logistic regression analysis is used to develop models for predicting corporate bankruptcy. The bankruptcy prediction models are presented below:

Year-1: $\mathrm{Z}=-6.578 \mathrm{xSF} / \mathrm{TA}-7.716 \mathrm{xEBIT} / \mathrm{TL}-1.643 \times \mathrm{XALE} / \mathrm{TA}+4.081$

Year $-2: Z=-9.039 x E B I T / T L-1.065 x$ SALE/CA +3.661

Year -3: $\mathrm{Z}=25.181 \mathrm{xEBIT} / \mathrm{TA}-19.847 \mathrm{xEBIT} / \mathrm{TL}-1.178 \mathrm{x}$ SALE/TA +1.189

The $\mathrm{Z}$ score obtained from the model can be transformed into a probability using the logistic transformation $\mathrm{P}=1$ / $\left(1+\mathrm{e}^{-\mathrm{z}}\right)$. The cut-off value is 0.5 . It means that if the estimated probability calculated as above is greater than 0.5 the company would be predicted as bankrupt.

Table 4. Classification Results- Logistic Regression

\begin{tabular}{|c|c|c|c|c|c|}
\hline & \multicolumn{4}{|c|}{ Predicted } \\
\hline & & & Non-Bankrupt & Bankrupt & Percent Correct \\
\hline \multirow[t]{3}{*}{ Year -1} & Observed & Non-Bankrupt & 16 & 6 & 72.73 \\
\hline & & Bankrupt & 5 & 17 & 77.27 \\
\hline & Overall Percent Correct & & & & 75.00 \\
\hline \multirow[t]{3}{*}{ Year -2 } & Observed & Non-Bankrupt & 13 & 9 & 59.09 \\
\hline & & Bankrupt & 9 & 13 & 59.09 \\
\hline & Overall Percent Correct & & & & 59.09 \\
\hline \multirow[t]{3}{*}{ Year -3} & Observed & Non-Bankrupt & 14 & 8 & 63.64 \\
\hline & & Bankrupt & 9 & 13 & 59.09 \\
\hline & Overall Percent Correct & & & & 61.36 \\
\hline
\end{tabular}

The results obtained by using logistic regression on the holdout sample are presented in Table 4.The results indicate that the accuracy rate fall from 75.00 per cent one year prior to bankruptcy to 59.09 per cent two years prior to bankruptcy. For the third year prior to bankruptcy the accuracy rate slightly increases to 61.36 per cent.

\subsection{Neural Network}

To develop the neural network bankruptcy prediction model the sample of 72 bankrupt and 72 non-bankrupt companies is partitioned into training, testing and holdout samples. The training sample comprises the data records used to train the neural network. 40 bankrupt and 40 non-bankrupt companies were assigned to the training sample in order to obtain a model. The testing sample is an independent set of data records used to track errors during training in order to prevent overtraining. 10 bankrupt and 10 non-bankrupt companies were assigned to the testing sample. 
The holdout sample is another independent set of data records used to assess the final neural network. Remaining 22 bankrupt and 22 non-bankrupt companies were assigned to the holdout sample.

Table 5. Classification Results- Neural Network

\begin{tabular}{|c|c|c|c|c|c|c|}
\hline & & & \multicolumn{4}{|c|}{ Predicted } \\
\hline & & & & Non-Bankrupt & Bankrupt & Percent Correct \\
\hline \multirow[t]{4}{*}{ Year -1} & Observed & & Non-Bankrupt & 20 & 2 & 90.91 \\
\hline & & & Bankrupt & 8 & 14 & 63.64 \\
\hline & Overall & Percent & & & & \\
\hline & Correct & & & & & 77.27 \\
\hline \multirow[t]{3}{*}{ Year -2 } & Observed & & Non-Bankrupt & 15 & 7 & 68.18 \\
\hline & & & Bankrupt & 9 & 13 & 59.09 \\
\hline & $\begin{array}{l}\text { Overall } \\
\text { Correct }\end{array}$ & Percent & & & & 63.64 \\
\hline \multirow[t]{3}{*}{ Year -3 } & Observed & & Non-Bankrupt & 18 & 4 & 81.82 \\
\hline & & & Bankrupt & 11 & 11 & 50.00 \\
\hline & $\begin{array}{l}\text { Overall } \\
\text { Correct }\end{array}$ & Percent & & & & 65.91 \\
\hline
\end{tabular}

The results obtained by using neural network on the holdout sample are presented in Table 5. It is observed that the accuracy rate of the model falls from 77.27 per cent one year prior to bankruptcy to 63.64 per cent two years prior to bankruptcy and then rises to 65.91 per cent for third year prior to bankruptcy.

\subsection{Comparison of Results}

This section compares the results of the three different methods used in this study.

Table 6.Comparative Classification Results

\begin{tabular}{llll}
\hline & Multiple Discriminant Analysis & Logistic Regression & Neural Network \\
\hline Overall Percent Correct & & & \\
Year-1 & 70.45 & 75.00 & 77.27 \\
Year-2 & 61.36 & 59.09 & 63.64 \\
Year-3 & 61.36 & 61.36 & 65.91 \\
\hline
\end{tabular}

These results are presented in Table 6. The results indicate that neural network achieved the highest overall classification accuracy for all the three years prior to bankruptcy. Multiple discriminant analysis and logistic regression produce comparable results.

\section{Conclusion}

This study attempts to develop and compare the performance of bankruptcy prediction models using multiple discriminant analysis, logistic regression and neural network for Indian listed companies. The dataset consists of 72 matched pairs of bankrupt and non-bankrupt companies. The bankrupt companies had failed between the periods 1991 to 2013. Accuracy rates for years one, two and three prior to bankruptcy for neural network are 77.27, 63.64 and 65.91 per cent respectively, for logistic regression are 75.00, 59.09 and 61.36 per cent and for multiple discriminant analysis $70.45,61.36$ and 61.36 per cent.

The results indicate that compared to multiple discriminant analysis and logistic regression, neural network has the highest prediction accuracy for all the three years prior to bankruptcy. Thus due to its comparative advantage neural network modeling should be in the forefront of professional attention so as to be used as successfully as possible in bankruptcy prediction of Indian companies.

This study can be further improved in future research through the introduction of non-financial variables since previous literature (Grunert, Norden \& Weber, 2005) suggest that these kinds of variables significantly improve the prediction accuracies of bankruptcy models. Also this study covers only listed Indian companies, further research can be done on relatively small sized private companies in India.

\section{References}

Altman, E. I. (1968). Financial ratios, discriminant analysis and the prediction of corporate bankruptcy, Journal of Finance, 23(4), 589-609. http://dx.doi.org/10.1111/j.1540-6261.1968.tb00843.x

Altman, E. I., Marco, G. \& Varetto, F. (1994). Corporate distress diagnosis: Comparisons using linear discriminant 
analysis and neural networks (the Italian experience), Journal of banking \& finance, 18(3), 505-529. http://dx.doi.org/ 10.1016/0378-4266(94)90007-8

Beaver, W. H. (1966). Financial ratios as predictors of failure, Journal of accounting research, Empirical Research in Accounting: Selected Studies 1966, 71-111. http://dx.doi.org/10.2307/2490171

Boritz, J. \& Kennedy, D. (1995). Effectiveness of neural network types for prediction of business failure, Expert Systems with Applications, 9(4), 504-512. http://dx.doi.org/10.1016/0957-4174(95)00020-8

Bredart X. (2014). Bankruptcy prediction models using neural networks, Accounting and Finance Research, 3(2), 124-128. http://dx.doi.org/10.5430/afr.v3n2p124

Caudill M. (1989). Neural network primer, The Magazine of Artificial Intelligence in Practice, Miller Freeman Publications.

Charitou, A., Neophytou, E., \& Charalambous, C. (2004). Predicting corporate failure: empirical evidence for the UK, European Accounting Review, 13(3), 465-497. http://dx.doi.org/ 10.1080/0963818042000216811

Coats, P. K. \& Fant, L. F. (1993). Recognizing financial distress patterns using a neural network tool, Financial Management, 22(3), 142-155. http://www.jstor.org/stable/3665934

Cybinski, P. (2001). Description, explanation, prediction - the evolution of bankruptcy studies? Managerial Finance, 27(4), 29 - 44. http://dx.doi.org/10.1108/03074350110767123

Dielman, T.E. (1996). Applied Regression for Business and Economics (Boston: Duxbury Press)

Fitzpatrick, P. (1932). A comparison of ratios of successful industrial enterprises with those of failed firms, Certified Public Accountant, 2, 598-605.

Grunert, J., Norden, L. \& Weber M. (2005). The Role of Non-Financial Factors in Internal Credit Ratings, Journal of Banking and Finance, 29(2), 509-531. http://dx.doi.org/10.1016/j.jbankfin.2004.05.017

Kerling, M. \& Poddig, T. (1994). Klassifikation von Unternehmen mittels KNN. In: Rehkugler, H. -Zimmermann, H. G. (eds): Neuronale Netze in der Ökonomie. München: Vahlen Verlagpp. 424-490.

Merwin, C. L. (1942). Financing small corporations in five manufacturing industries, 1926-1936, National Bureau of Economic Research, New York, NY.

Moriss, R. (1997). Early Warning Indicators of Corporate Failure (Aldershot: Ashgate).

Odom, M. D. \& Sharda, R. (1990). A neural network model for bankruptcy prediction. In: Proceeding of the International Joint Conference on Neural Networks, San Diego, 17-21 June 1990, Volume II.IEEEE Neural Networks Council, Ann Arbor, 163-171. http://dx.doi.org/10.1109/IJCNN.1990.137710

Ohlson, J. A. (1980). Financial ratios and the probabilistic prediction of bankruptcy, Journal of accounting research, 18(1), 109-131. http://dx.doi.org/10.2307/2490395

Ong, S.W., Yap, V.C. \& Roy, W.L. (2011). Corporate failure prediction: a study of public listed companies in Malaysia, Managerial Finance, 37(6), 553 - 564. http://dx.doi.org/ 10.1108/03074351111134745

Polemis, D. \& Gounopoulos, D. (2012). Prediction of distress and identification of potential M\&As targets in UK, Managerial Finance, 38(11), 1085 - 1104. http://dx.doi.org/ 10.1108/03074351211266801

Ramser, J. \& Foster, L. (1931). “A Demonstration of Ratio Analysis”, Bulletin 40, Bureau of Business Research, University of Illinois, Urbana.IL.

Salchenberger, L. M., Cinar, E. \& Lash, N. A. (1992). Neural Networks: A New Tool for Predicting Thrift Failures, Decision Sciences, 23(4), 899-916. http://dx.doi.org/10.1111/j.1540-5915.1992.tb00425.x

Ugurlu, M. \& Aksoy, H. (2006). "Prediction of corporate financial distress in an emerging market: the case of Turkey", Cross Cultural Management: An International Journal, 13(4), 277-295. http://dx.doi.org/10.1108/13527600610713396

Virág, M. \& Kristóf, T. (2005). Neural Networks in Bankruptcy Prediction-A Comparative Study on the Basis of the First Hungarian Bankruptcy Model, Acta Oeconomica, 55(4), 403-426. http://dx.doi.org/10.1556/AOecon.55.2005.4.2

Winakor, A. \& Smith, R. (1935). Changes in the financial structure of unsuccessful industrial corporations, Bulletin 51, Bureau of Business Research, University of Illinois, Urbana.IL.

Zhang, G., Hu, M., Patuwo, B.E. \& Indro, D.C. (1999). Artificial neural networks in bankruptcy prediction: General framework and cross-validation analysis, European Journal of Operations Research, 116(1), 16-32. http://dx.doi.org/ 10.1016/S0377-2217(98)00051-4 